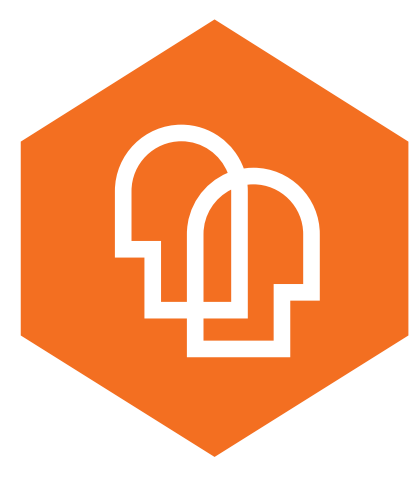

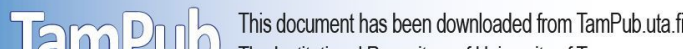
The Insititutional Repository of University of Tampere

VOLUME 13 ISSUE 3

The International Journal of

\section{New Media, Technology, \\ and the Arts}

Facilitating Creative Media Production through the Pedagogy of Multiliteracies

A Case Study with Vulnerable Young People 


\section{EDITOR}

Barbara Formis, University Paris I, France

HEAD OF JOURNAL PRODUCTION

McCall Macomber, Common Ground Research Networks, USA

\section{EDITORIAL ASSISTANT}

Crystal Lasky Robinson, Common Ground Research Networks, USA

\section{ADVISORY BOARD}

The Arts in Society Research Network recognizes the contribution of many in the evolution of the Research Network. The principal role of the Advisory Board has been, and is, to drive the overall intellectual direction of the Research Network. A full list of members can be found at http://artsinsociety.com/about/advisory-board.

\section{PEER REVIEW}

Articles published in The International Journal of New Media Technology and the Arts are peer reviewed using a two-way anonymous peer review model. Reviewers are active participants of The Arts in Society Research Network or a thematically related Research Network. The publisher, editors, reviewers, and authors all agree upon the following standards of expected ethical behavior, which are based on the Committee on Publication Ethics (COPE) Codes of Conduct and Best Practice Guidelines. More information can be found at: http://artsinsociety.com/journals/model.

THE INTERNATIONAL JOURNAL OF NEW MEDIA, TECHNOLOGY AND THE ARTS http://artsinsociety.com

ISSN: 2326-9987 (Print)

ISSN: 2327-1787 (Online)

http://doi.org/10.18848/2326-9987/CGP (Journal)

First published by Common Ground Research Networks in 2018 University of Illinois Research Park

2001 South First Street, Suite 202

Champaign, IL 61820 USA

$\mathrm{Ph}:+1-217-328-0405$

http://cgnetworks.org

The International Journal of New Media, Technology and the Arts is a peer-reviewed, scholarly journal.

\section{COPYRIGHT}

(C) 2018 (individual papers), the author(s)

(C) 2018 (selection and editorial matter)

Common Ground Research Networks

\section{(이요 $\odot \odot$}

Some Rights Reserved.

Public Licensed Material: Available under the terms and conditions of the Creative Commons Attribution-NonCommercial-NoDerivatives 4.0 International Public License (CC BY-NC-ND 4.0). The use of this material is permitted for non-commercial use provided the creator(s) and publisher receive attribution. No derivatives of this version are permitted. Official terms of this public license apply as indicated here: https:/creativecommons.org/licenses/by-nc-nd/4.0/legalcode

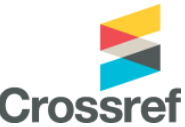

Common Ground Research Networks, a member of Crossref

\section{ARTICLE SUBMISSION}

The International Journal of New Media, Technology and the Arts publishes quarterly (March, June, September, December). Please visit http://artsinsociety.com/journals/call-for-papers to find out more about the submission process.

\section{ABSTRACTING AND INDEXING}

For a full list of databases in which this journal is indexed, please visit http://artsinsociety.com/journals/collection.

\section{RESEARCH NETWORK MEMBERSHIP}

Authors in The International Journal of New Media, Technology and the Arts are members of The Arts in Society Research Network or a thematically related Research Network. Members receive access to journal content. To find out more, visit

http://artsinsociety.com/about/become-a-member.

\section{SUBSCRIPTIONS}

The International Journal of New Media, Technology and the Arts is available in electronic and print formats. Subscribe to gain access to content from the current year and the entire backlist.

Contact us at support@cgnetworks.org.

\section{ORDERING}

Single articles and issues are available from the journal bookstore at https://cgscholar.com/bookstore.

\section{HYBRID OPEN ACCESS}

The International Journal of New Media, Technology and the Arts is Hybrid Open Access, meaning authors can choose to make their articles open access. This allows their work to reach an even wider audience, broadening the dissemination of their research. To find out more, please visit http://artsinsociety.com/journals/hybrid-open-access.

\section{DISCLAIMER}

The authors, editors, and publisher will not accept any legal responsibility for any errors or omissions that may have been made in this publication. The publisher makes no warranty, express or implied, with respect to the material contained herein. 


\title{
Facilitating Creative Media Production through the Pedagogy of Multiliteracies: A Case Study with Vulnerable Young People
}

\author{
Mari Pienimäki, ${ }^{1}$ University of Tampere, Finland
}

\begin{abstract}
As the focus in media education has shifted more from the analysis of media texts to their production, the question of creativity has simultaneously come into the spotlight. The skills of creative media production enable people to get their voices heard and to participate in our mediatised society. The media educational study "Young People in the Limelight" examines how to inspire youth to participate, particularly in media culture. Nearly 100 vulnerable young people aged fifteen to twenty-two years participated in the action research. They had, for example, social or learning difficulties. The qualitative data mainly include diaries and interviews. In this article, it is asked how the pedagogy of multiliteracies can facilitate vulnerable young people's creative work within media production in the context of youth work. The results demonstrate four factors of pedagogy facilitating their creative work: building motivation and selfconfidence, creating an encouraging atmosphere, facilitating creative media production, and providing opportunities to publish in authentic settings. The study confirms the significance of the pedagogy of multiliteracies in a youth work context. Furthermore, it raises the value of the many-sided reception of art and media culture, use of the methods of creativity, and publishing in authentic settings.
\end{abstract}

Keywords: Young People, Vulnerable, Creativity, Media Production, Pedagogy of Multiliteracies, Competence

\section{Introduction: Desire for Competence}

$\mathrm{T}$ There is a growing trend around the Western world among young people skilful with technology to create media content on their own terms and to publish it online. In a media educational study in Finland, it was discovered that youth, in fact, desire to experience skilfulness and competence. The action research called Young People in the Limelight: Towards Agency through Multiliteracies (YPAM) (2015-2017) invited vulnerable young people as coresearchers to explore in art-based media workshops what inspires youth to participate in society, in particular, media culture. It was hypothesised that the young participants would be interested in developing their creative self-expression skills. Instead, it happened that many young people wished to master, for instance, camera and editing techniques and technology in general (see also Bloustein 2007; Pariser, Castro, and Lalonde 2016; Vickery 2014). However, behind these wishes appeared to be a desire to do well and feel competent, as they believed these skills to contribute to innovative art and media content. Most participants did not comprehend the significance of creativity in high-quality work, and many had difficulties with creativity. After all, a goal of the workshops turned out to be to help young people gain an experience of competence through facilitating their creative work within media production.

\section{Creative Media Production}

Creativity is not just a topic within the field of arts; creative thinking and work take place in various fields of life and society, from cooking to the media industry. While the focus in media education has shifted more from the analysis of media texts to their production, this shift has

\footnotetext{
${ }^{1}$ Corresponding Author: Mari Pienimäki, Kalevantie 4, Faculty of Management, University of Tampere, Tampere, Pirkanmaa, 33014, Finland. email: mari.pienimaki@uta.fi
} 
brought the question of creativity into the spotlight as well. Banaji and Burn (2007) criticise that the idea of creativity has remained vague in these discussions. After analysing diverse notions of creativity, they find culturalist perspectives useful for media education. Such perspectives of creativity are most familiar in the field of cultural studies.

Cultural studies focus on the contexts where meanings are constructed, such as inspecting the meaning-making practices of media texts in the production and reception of media. In addition to production, the reception of media is considered an active process rather than the passive receiving of audience (Grossberg 1989). However, contemporary audiences are not only active receivers; they are in diverse relations with media, from becoming more than consumers and users to also being active creators of media content (Kotilainen 2009). This situation forms a need to reflect media production in media education more than ever before, especially with youth who are active creators of media. Today, many media educators promote hands-on media education because, in addition to becoming media literate, the skills required to produce media content purposefully and to be creative enable young people to get their voices heard and so to participate in our mediatised society. Furthermore, participatory media education seems to inspire youth, especially withdrawn people, to inspect the critical aspects of media more than merely analysing the media content. (See also Buckingham 2003; Jenkins et al. 2009; Kotilainen 2009.)

Jenkins et al. (2009) emphasise that creative skills such as play, simulation, performance, and remixing are today's core media literacy skills, making active and full participation possible in contemporary society. The production of media content is seen as a creative and selfexpressive process in cultural studies as well (Grossberg 1989). However, in this context, creativity is not linked with the idea of creative genius or aesthetic taste. Instead, as in this text, creativity refers to the active process in which people apply the acquired cultural practices of meaning-making in their own media production at its best, with a reflective manner that transforms society. Therefore, adjectives like fine and innovative used later in this text next to the words art and media content do not suggest a judgement about the aesthetic quality of the work of the youth. They refer instead to the depth the young people have grasped the cultural meaningmaking practices and/or to their own understanding of their success of applying these practices in their media production.

According to Sefton-Green (2000), creativity tends to be considered within cultural or social paradigms rather than from psychological viewpoints. He stresses that this tendency does not imply that developmental psychology is not valuable within this debate. In the YPAM study, in addition to the development of young people's media production skills, the support of creativity was a central factor in promoting their experience of competence, which is one of the human needs or motivations forming psychological growth and wellbeing (Deci and Ryan 2000; Ryan, Huta, and Deci 2008; Silbereisen and Lerner 2007). In other words, creativity as a factor in the formation of competence has significance in youth development and empowerment. For this reason also, it is valuable to inspect how creative work, especially of vulnerable youth, can be supported. Vulnerable refers here to young people who have diminished motivation or ability to make personal life choices or who lack skills for everyday life due to situational, psychological, or physiological reasons (Liamputtong 2007). So, they are at risk of marginalisation and dropping out of society.

In the past two decades, the pedagogy of multiliteracies has gained ground, especially in the school context around Western culture. The pedagogy was launched in 1990s by the so-called New London Group, who realized the increasing cultural and linguistic diversity of societies due to globalisation, and the multiple new forms of text associated with information and communication technologies (Cazden et al. 1996). The Group was concerned that not all students benefit from current methods and conditions of teaching and learning due this changing social environment. Thus, there was a need to form a new approach to literacy pedagogy that they called "multiliteracies" (1996). 
The pedagogy of multiliteracies contains four intertwined factors. Situated Practice relates to creating a motivation for learners: the lifeworlds and existing knowledge of learners are acknowledged as starting points of education, and their identities are recruited as a motivation in learning. Overt Instruction refers to teachers' purposeful interventions to scaffold learning processes: to help the learners recognize the key features of their experiences and activities as the target of analysis and, in addition, to offer them useful concepts for the analysis or to assist them to develop their own metalanguage. In the phase of Critical Framing, the learners contextualize their growing understanding of the target of their analysis in relation to history, cultures, politics, ideologies, etc. and thus view things from a distance. Transformed Practice means returning to Situated Practice and re-practicing things in a reflective manner based on what was learned in previous phases. Overall, the pedagogy of multiliteracies promotes the agencies of learners through transformative practices, and it endorses collaborative and informal learning environments and practices (Broderick 2014; Cazden et al. 1996; Cope and Kalantzis 2010).

In this article, it is examined how the pedagogy of multiliteracies can support the creative work of young people in the context of youth work, where it has been less used. However, as youth work does not possess demanding learning objectives set by a curriculum, the four instructional phases of the pedagogy - Situated Practice, Overt Instruction, Critical Framing, Transformed Practice - were not always rigorously followed in the YPAM workshops. Yet, the workshops were based on participatory media education with transformative, creative, and collaborative aims. So, in this article, it is asked how the pedagogy of multiliteracies can facilitate vulnerable young people's creative work within media production in the context of youth work.

\section{Research Project Young People in the Limelight}

In Finland, about 5 percent of all fifteen-to-twenty-nine-year-olds are marginalised, and many more are at risk of dropping out of society (Myrskylä 2012). Although this societal problem is not as serious as in many European countries, it has been recognised as a challenge to be addressed as it seems to persist. The nationwide case study Young People in the Limelight aims to discover new ways to support vulnerable youth to participate in society, particularly media culture, and to enhance their multiliteracies, especially skills and knowledge of media production. The goal is to develop a media pedagogy, based on the pedagogy of multiliteracies, that encourages vulnerable youth to express themselves in and through media.

The young participants of YPAM were unemployed, struggled with social or learning difficulties, lived through a challenging family situation, or had an immigrant background. In most ways, they acted as any youth, negotiating between diverse culturally defined roles and memberships and shifting between different positions as their desires and practices, including media use, are on the move (Asthana 2012). Altogether, nearly 100 mostly fifteen-to-twenty-two-year-old young people enrolled in the media workshops, yet about one-third dropped out after the first meetings.

The study includes seven art-based media workshops (sub-studies), which were conducted in collaboration with diverse youth institutions, such as a special youth house, a youth café, a school-like daily workshop run by a city, and a reception centre for young asylum seekers. All workshops, except one, were voluntary for participants. A pilot and four workshops focused on photography. The rest of the workshops concentrated on film, theatre, and creative writing. Eight researchers designed and organised the workshops in cooperation with youth workers and teachers of each institution. In the workshops, the youth were encouraged to create artistic, selfexpression-based media content (photographs, videos, fairy tales, poems, a theatre play) and publish it online or offline (in social media, a magazine, an exhibition, or on stage). The selfexpression-based media tasks varied from quick assignments to entire projects, such as an art exhibition and theatre play. The quick photography tasks used prompts like "Think of an adjective that is important for you and take a photograph illustrating it," "City treasure: take a 
photograph of something in your neighbourhood that others do not usually notice" (see Hongisto 2015), "Take a photograph of some societal or personal issue you want to influence" (see Kiuru 2016; Myllynen 2016), and "Unusual self-portrait: take a photograph representing you without showing your face." In the creative writing workshops, there were tasks like "Write a poem by innovatively utilising internet search engines," "Create a meme concerning the activities or people at the workshop or people in general," "Produce a manuscript of a short movie," and "Write a fairy tale" (see Puska 2016).

Action research in the case of YPAM means trying to understand a practical, pressing issue of youth marginalisation and to improve this situation directly through the workshops and by developing a media pedagogical model for institutions that work with youth. The action research cycle with phases of planning, acting, observing, and reflecting was operationalised within each sub-study (workshop) from one to several times, depending on the context of the study and time in use. (Reason and Bradbury 2006.) Furthermore, the pilot and following seven workshops can be understood as a spiral of one large action research, as they were implemented partly sequentially, and the insights of the first workshop were utilised in the second, the results of which benefitted the third and so on. In the YPAM study, understanding and knowledge were built up through these repeated flexible and transformative cycles (Pienimäki and Kotilainen 2018).

The data of YPAM is mainly qualitative, being collected through mixed methods (Cresswell 1998). It includes ten researchers' observation diaries, twenty-seven individual interviews with youth, six interviews with seven youth workers, a discussion among two researchers, four individual peer interviews with youth as interviewers and interviewees, a peer interview as a radio show with three young people, summaries of World Café discussions with twelve topics (groups) among youth workers and researchers at two YPAM seminars, and media content made by the youth (e.g. photographs, fairy tales). All interviews are transcribed. Furthermore, the youth completed forty-four background questionnaires (regarding e.g. age, country of birth, media use) and twenty-seven questionnaires about their workshop experiences after the workshops. The extensive qualitative data was categorised (i.e., coded) with two different sets of categories in a total of twenty-one categories, with the help of the Atlas.ti software programme. The categories were formed by a preliminary reading of the data, the key words of YPAM, and by reviewing previous literature on the matter. The categories include, for instance, motivation; social interaction; art and self-expression; identity; and, furthermore, social-cultural media participation in relation to a young individual, an institution, and technology.

\section{Facilitating Vulnerable Young People to Become Creative}

Some young people of YPAM who already possessed technical expertise or had received plenty of technical guidance were aware that creativity and self-expression play a significant part in the creation of innovative media content and artworks. However, most youth talked about their aspiration for technical mastery. Nonetheless, most of them developed an interest to improve their creative self-expression skills during the workshops.

Many vulnerable young people appeared to have a low self-image, so they had very little belief in their skills and not much courage to try to create something fine. However, after they received some positive feedback and were pleased with their own work, there appeared a significant increase in their motivation to engage with media tasks and to publish their media content (Broderick 2014; Carr and Jitendra 2000). Consequently, it was discovered that the vulnerable youth should be challenged to excel themselves in creative work. However, this process turned out to be a challenge by itself, as many YPAM youth had difficulties beginning a creative process and performing with creativity.

When analysing the YPAM data, four key factors of pedagogy were identified that facilitated the vulnerable young people's creative work within media production and their participation and sense of competence: building motivation and self-confidence, creating an 
encouraging atmosphere, facilitating creative media production, and providing opportunities to publish in authentic settings.

\section{Building Motivation and Self-Confidence to Take Up a Creative Task}

Many young people of YPAM had a general lack of interest. Despite this fact, they mostly accomplished the presented tasks, but only from a sense of duty or obligation. This may be because they could not imagine the pleasant experiences they might gain from doing the tasks and so they were not eager to actively start to create something (Broderick 2014). Thus, they often underachieved in the tasks, especially in the beginning of the workshops. Getting the youth to seriously embrace a creative task was one of the biggest challenges in the workshops. It became important to make connections to their lifeworlds and identity and strengthen their selfconfidence to build their motivation to initiate a creative work.

As most youth today, the vulnerable young people of YPAM were interested in some aspects of media, especially about entertainment and instant communication. Many young people had also produced some artistic media content on their own but lost interest in it for some reason. In the workshops, the opportunity to produce media content was not enough alone to form a motivation. However, when the suggested media tasks had an explicit connection to their lifeworlds and so to their personal interests, their motivation arose (see also Broderick 2014; Cope and Kalantzis 2010; Marsh 2012). The obvious fact is that they were attached to the issue of their interest in their lifeworlds. This connection had, though, another, deeper meaning in building their motivation. The young people had plenty of knowledge, even skills, related to their interest, which formed an experience of expertise and competence that in turn built their motivation to engage seriously with the tasks and to finish them well. The experience of competence has been noted as a motivational factor also by other researchers (Deci and Ryan 2000; Ryan, Huta, and Deci 2008).

The motivation of the young people arose through identity-related tasks as well. The significance of these tasks was threefold. First, since youth is a phase of life during which people reflect on their identities in particular, the vulnerable young people were naturally interested in identity processing and thus in the tasks (Cope and Kalantzis 2010). Second, as many young people had a negative self-image, these tasks opened an opportunity to process their identity and potentially to start looking at themselves in a more positive light, which desirably affected their motivation (Salvio 2013). Third, the identity-related tasks provided the youth a chance to explore and discover their interests and strengths. The advancement of self-knowledge and consequently, ability to lean on their strengths, increased their chances to excel themselves and thus to gain self-confidence. (Black, Walsch, and Taylor 2011; Carr and Jitendra 2000.) In the strengthening of self-confidence, all positive feedback on their competence and identity, such as verbal comments from peers, were important as well. However, there was a fine line to walk, as many young people were simultaneously afraid to portray their identities, and a prospect for disempowerment seemed to always exist as their identities were put on the table.

\section{Creating an Encouraging Atmosphere to Facilitate the Birth of Creativity}

Many vulnerable youth of YPAM were extremely sensitive to the atmosphere of the workshops. If they sensed any hostility from adults or peers, they withdrew or dropped out of the voluntary workshops. If they experienced unpleasant judging or even a prospect of it, they were not likely to participate in the tasks or even to attend the workshops. In fact, many youth said at first that they did not wish to receive any feedback of their work. Consequently, it was crucial to create a non-judgmental and friendly and atmosphere.

The fact that the YPAM workshops were held mostly in the context of youth work was helpful, since it meant that the young people did not receive any grades for their media content. 
Likewise, Vickery (2014) discovered that if the young people do not receive grades or credit for their work, they feel more comfortable messing around, exploring, failing, and experimenting (Broderick 2014). In addition to enhancing participation, playful experimenting created a chance to lead into an innovative work and so to excel oneself.

The fact that most media tasks were artistic in nature relaxed many vulnerable youth as well, as they knew that in art it is difficult to define right and wrong. In other words, the context of the art world appeared to be by itself a facilitating factor in their media production. Also, informal activities (e.g., photography excursions outdoors) and working methods (e.g., peer teaching, project-based learning) proved to be valuable in forming a non-judgmental environment, as they broke down power hierarchies among youth and adults and created a gentle and inspiring atmosphere. For example, teaching peers film editing provided the young tutors a position as experts and so an opportunity to feel competent, which improved their motivation and engagement.

Regardless of the matter that participants resisted feedback, it was crucial to comment explicitly on their work and implicitly on their identities through the tasks. The positive comments formed an uplifting and encouraging atmosphere. The young people's resistance arose merely from the matter that they were used to and afraid of receiving discouraging feedback. In fact, after receiving pleasant feedback, they started to ask for more comments. Positive comments provided them in turn with feelings of success and grew their sense of competence, which seemed to enhance their willingness to participate in the future. However, giving feedback was a delicate matter that instantly affected the atmosphere and participation of the young people. The YPAM pedagogues put much effort in the manner of giving feedback, concentrating mainly on the success of the youth.

\section{Facilitating Creative Media Production}

In the YPAM workshops, a great challenge was also posed by creative work itself. The very first impression, yet incorrect, was that many young participants were not innovative, as they had much difficulty with creativity. It was hypothesised that the vulnerable had not previously received an opportunity, such as in school, to do as they wish and for that reason they had lost their interest in creative work. In addition, some asylum seekers had not even attended school. For example, in the creative writing workshop, young participants were offered an opportunity to write a manuscript of a short movie fully from their interests, and in one photography workshop, they were given a chance to do whatever kind of photography project they liked. However, many young people could not come up with any ideas on their own.

In interviews after the workshops, many youth revealed that their minds went "blank" when there was too much freedom. Likewise, Rodríguez-Jiménez and Gifford (2010) found in their participatory art workshop with young refugees that the lack of structure was paralysing rather than liberating. Also in YPAM, it was discovered as important to provide tasks with clear structure and boundaries for the vulnerable young people so that they could grasp the presented task. Yet, a few individuals, who had previously accomplished plenty of creative work, felt that the structured tasks limited their creativity, and so they experienced a lack of interest towards the task and had trouble accomplishing it. Consequently, the needs and skills of each vulnerable young person should be considered separately.

As many youth had low self-confidence, they were easily inclined to interpret the tasks as too difficult and were afraid of failing. At such occasions, they did not try seriously or gave up totally. So, offering them realistic tasks that they interpreted to be achievable was a key factor to get them engaged with the tasks. Yet if a task was not challenging enough, the experience of excelling oneself was not likely to appear. Therefore, it was crucial to determine appropriate tasks and to properly introduce them as interesting but not too difficult. Constructive feedback was also important, as it improved their self-reflection skills. 


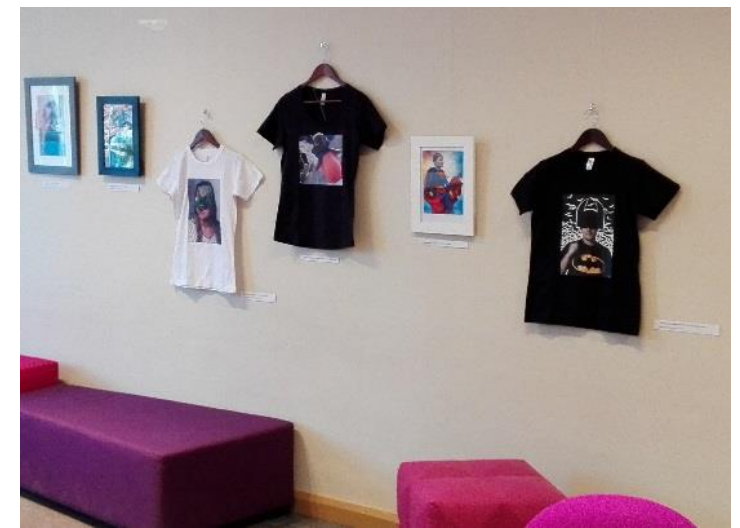

Figure 1: Through using a method of a tree of ideas, the young people came up with a photography exhibition, which presented, e.g., self-portraits as a superhero printed on a T-shirt. The method is based on writing down different ideas and interests and then mixing them up. Source: Pienimäki 2016

Many participants needed help in the awakening of creativity in order to come up with ideas about how to accomplish the presented tasks. Although most of them had constant access to the internet and, in principle, they were able to receive a wide variety of art and media culture, many seemed to have enjoyed our rich culture in a somewhat limited sense. In the workshops, the young people were provided plenty of opportunities to experience art and culture. For example, they were taken to art exhibitions and other inspiring places, like a photography studio and a media house. They made acquaintances with artists. They were shown examples of innovative artworks and media content by pedagogues and given ideas of how to realise creative content. Many young people found it hard to imagine anything without very concrete examples of what to do.

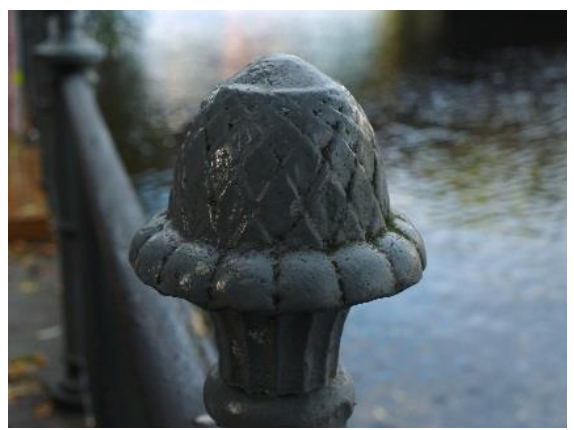

Figure 2: This photo was taken while using the walking method. The task was to photograph something others do not usually see.

Source: veera emilia 2015

Talking about art and media culture was also important for the reason that many young people were not consciously able to utilise the meaning-making practices of Western culture (see also Buckingham 2003). For example, in photography workshops, it was discussed how different angles and frame sizes affect the meaning of a photograph. The knowledge of these meaningmaking practices helped them to create art and media content purposefully, to produce meanings that they intended to provoke. At the same time, they acknowledged how differently diverse audiences can interpret their media content and that these interpretations can never be fully governed, especially in visual media. 


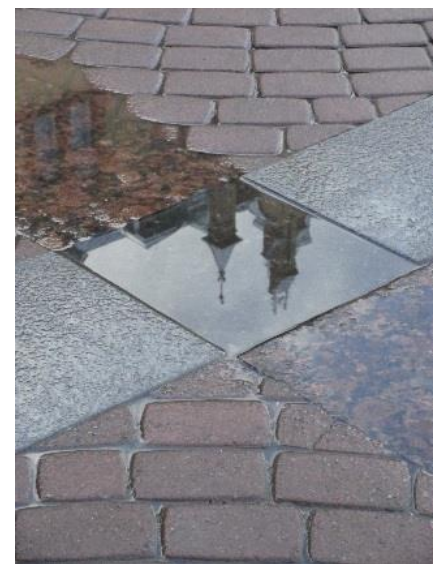

Figure 3: This photo was taken while using the walking method. The task was to photograph something others do not usually see. Source: SAV 2015

Even after experiencing diverse examples of art and media, many times the participants often still only imitated the provided examples. Even though imitation is often opposed in art and media education, the young people seemed to learn a lot about media production merely through imitating (see also Hobbs and Moore 2014). It was surprising as well that quite a few of them later forgot that their work was much of an imitation, and they felt pride in being able to produce such innovative content. Yet, it was discovered that many creative methods (e.g., a word list, a tree of ideas) facilitated the youth to become significantly more creative (see Figure 1).

In a couple of photography workshops, a walking method was experimented with as a tool of creativity during outdoor excursions. In this method, the participants are asked to walk slowly around an environment, to perceive it with multiple senses (sight, hearing, sense of smell, etc.) and to pay attention only to a few aspects of the environment. The aim is to sensitise one toward a multisensory and holistic perspective and to an experience of a bodily presence (Keskitalo 2006). In the excursions, observing angles and frame sizes gave enough impulse to start photographing, and yet, it did not limit the young people's creative work. The multisensory perceiving appeared to increase their alertness and so, they noticed plenty of interesting subject matters (see Figures 2 and 3). In other words, the vulnerable youth benefited greatly from diverse methods of creativity. Furthermore, as their work became more innovative, they received greater experiences of competence and excelling themselves, which increased their motivation and participation in the future.

\section{Offering Opportunities to Publish Creative Work in Authentic Settings}

A part of the research design of the YPAM project was to offer the young people opportunities to publish their creative work in authentic settings, in mainstream media (e.g., a youth magazine), social media (e.g., Instagram), and offline spaces (e.g., an art exhibition, a stage). The act of publishing was confirmed to have particular importance, as the young people appeared to interpret the offered opportunities of showing their work as a sign of their competence, strengthening their self-confidence and motivation to participate (see also Carr and Jitendra 2000; Charmaraman 2013; Hopkins 2010; Vickery 2014).

The vulnerable were especially motivated by opportunities to publish their work in a forum that was out of their ordinary field of action, such as in a real youth magazine or an art exhibition outside of the institution they usually gathered at or lived in. In these cases, they also put more effort into their creative work as they wanted to show their best work in these special forums, and of course, they more frequently excelled themselves. In addition, as they knew that there are gatekeepers in these publishing forums, as in mainstream media, they considered the act of 
publishing as a more significant sign of their success than showing their work in Instagram, for instance. However, the youth also appreciated publishing in social media because they realised that their friends and peers were more likely to see their work there. Obviously, getting peer affirmation is important for young people.

The participants gained knowledge about the production of media and the practices of the art world through the process of publishing, as well as facts influencing their creative work later. When they were hanging a photography art exhibition, they realised how an exhibition space can affect the perception of photographs and how photographs next to each other function in interaction, possibly even form meanings together that are beyond their individual content.

The act of publishing was yet another delicate matter, since it entailed a chance to receive feedback of one's creative work, which frightened some young people. Thus, some individuals were not eager to publish their artistic media content, especially in the beginning of the workshops, as they realised that they could not control the reception of their work. For these individuals, private feedback was appropriate to build their self-confidence and courage. On the other hand, feedback publicly and in front of peers such as through an opening speech of an exhibition or on social media forums appeared to further support the vulnerable youth's sense of competence, improving their motivation to participate and to excel themselves in future projects.

\section{Conclusion}

In the YPAM workshops, the pedagogy of multiliteracies proved to facilitate the creative media production of vulnerable young people in several ways. As the pedagogy and so the workshops as well were based on the idea of Situated Practice - taking the lifeworlds and identities of learners as an energy and a starting point of education - the workshops were able to build the motivation and self-confidence of vulnerable participants to take up a creative task. The identityrelated tasks also offered an opportunity to process one's identity, and furthermore, to potentially advance the birth of a more positive self-image and increased self-confidence. As the pedagogy of multiliteracies endorses informal, action-based design together with learners (Cazden et al. 1996; Cope and Kalantzis 2010), it formed an experimental and encouraging atmosphere facilitating the birth of creativity. It was also noticed that the context of the art world, youth work, and positive feedback contributed to the encouraging atmosphere.

The significance of Overt Instruction - scaffolding learning activities - was not fully understood before implementing the workshops. However, during the workshops, it became evident that most participants needed clearly structured tasks in order to grasp them. In addition, offering them realistic tasks, interesting yet achievable from their perspective, allowed them to accomplish a task more complex than one they could do on their own (see also Cazden et al. 1996).

It was realised that the youth needed many examples of art and media and diverse sources of inspiration, such as visits to exhibitions. However, it was noted that the methods of creativity, in particular, helped the participants to accomplish Transformed Practice, which is more than just an imitation of some artwork or media content. In other words, explicit information about the cultural meaning-making practices was not enough alone for the vulnerable to reach re-practice in a reflective, transformative manner. Furthermore, it was valuable that the re-practice would take place in authentic settings, while the youth learned more about media production and the practices of the art world through the publishing process. The opportunities to publish in authentic settings motivated them to engage with tasks and to excel themselves and raised their sense of competence. These opportunities also offered a chance to gain public feedback, affecting them even more than private commenting.

To sum up, the YPAM study confirms the constitutive ideas of the pedagogy of multiliteracies with vulnerable young people in the context of youth work. In addition, it raises the significance of the many-sided reception of art and media culture, the use of methods of creativity, and publishing in authentic settings. The YPAM study points out that supporting the 
creative work of vulnerable young people is important for two reasons: first, it improves their skills of media production and so their ability to get their voices heard in our mediatised society. Second, it promotes the experience of competence, which in turn appeared to increase the young people's self-confidence and motivation to participate. The motivation to participate in society is certainly a key feature in preventing the marginalisation of young people. Furthermore, the experience of competence is by itself a factor contributing to the wellbeing of young people (Deci and Ryan 2000; Silbereisen and Lerner 2007).

However, it is justified to ask if there are enough opportunities for the vulnerable young people to develop and perform their creative skills in school and in their spare time and so to experience a sense of competence. Are teachers able to offer enough places for creativity within their tight curriculums and to give enough attention and support for the vulnerable when classrooms are overcrowded with pupils? As youth work does not possess the demanding objectives of a curriculum, it has more opportunities to offer creative and playful situations for vulnerable youth. However, in many countries, the human and financial resources are tight in the context of youth work. In addition, although in Finland there are many special youth houses that even target vulnerable youth, there is still a need for even more creative art and media workshops for the vulnerable because empowerment requires a lengthy time to be established (Pienimäki and Kotilainen 2018). In other words, one short workshop (e.g., a few hours once a week during a semester) is just barely able to initiate an empowerment process for a vulnerable young person. A similar challenge appears when artists conduct community art projects for vulnerable groups. As the artists are often financed by project money, there is no continuity for their workshops. In future research, another critical point to inspect would be how to translate the improved creative skills into operable social capital and how to transfer the motivation to participate outside the workshops into social realities in schools and workplaces with great aims and strain (Hopkins 2010; Podkalicka and Staley 2009).

\section{Acknowledgement}

This article has been supported by Kone Foundation and Academy of Finland (SA 304146).

\section{REFERENCES}

Asthana, Sanjay. 2012. "Youth Media Imaginaries from around the World." New York: Peter Lang.

Banaji, Shakuntala, and Andrew Burn. 2007. "Creativity through a Rhetorical Lens: Implications for Schooling, Literacy and Media Education." Literacy 41 (2): 62-70. http://doi.org/10.1111/j.1467-9345.2007.00459.x.

Black, Rosalyn, Lucas Walsch, and Fiona Taylor. 2011. "Young People on the Margins: What Works in Youth Participation." Youth Studies Australia 30 (1): 42-48.

Bloustein, Gerry. 2007. "WWigging People Out': Youth Music Practice and Mediated Communities." Journal of Community and Applied Social Psychology 17 (6): 446-62. http://doi.org/10.1002/casp.938.

Buckingham, David. 2003. Media Education. Literacy, Learning and Contemporary Culture. Cambridge: Polity.

Broderick, Debora. 2014. "Collaborative Design: Participatory Culture Meets Multiliteracies in a High School Arts Community." Adolescent \& Adult Literacy 58 (3): 198-208. http://doi.org/10.1002/jaal.350. 
Carr, Tracy, and Asha K. Jitendra. 2000. "Using Hypermedia and Multimedia to Promote Project-Based Learning of At-Risk High School Students." Technology Trends 36 (1): 40-44. http://doi.org/10.1177/105345120003600106.

Cazden, Courtney, Bill Cope, Norman Fairclough, Jim Gee, Mary Kalantzis, Gunther Kress, Allan Luke, Carmen Luke, Sarah Michaels, and Martin Nakata. 1996. "A Pedagogy of Multiliteracies: Designing Social Futures.” Harvard Educational Review 66 (1): 60-92. http://newarcproject.pbworks.com/f/Pedagogy\%2Bof\%2BMultiliteracies_New\%2BLon don\%2BGroup.pdf.

Charmaraman, Linda. 2017. "Congregating to Create for Social Change: Urban Youth Media Production and Sense of Community." Learning, Media and Technology 38 (1): 102-15. http://doi.org/10.1080/17439884.2011.621956.

Cope, Bill, and Mary Kalantzis. 2010. "New Media, New Learning.” In Multiliteracies Motion: Current Theory and Practice, edited by David R. Cole and Darren L. Pullen, 87-104. London: Routledge.

Cresswell, John W. 1998. Qualitative Inquiry and Research Design: Choosing Among Five Traditions. Thousand Oaks, CA: SAGE.

Deci, Edward L., and Richard M. Ryan. 2000. "The 'What' and 'Why' of Goal Pursuits: Human Needs and the Self-Determination of Behavior." Psychological Inquiry 11 (4): 227-68. http://doi.org/10.1207/S15327965PLI1104_01.

Grossberg, Lawrence. 1989. "The Circulation of Cultural Studies." Critical Studies in Mass Communication 6 (4): 413-21

Hager, Paul, and Erica Smith. 2004. "The Inescapability of Significant Contextual Learning in Work Performance." London Review of Education 2 (1): 33-46.

Hobbs, Renee, and David C. Moore. 2014. "Cinekyd: Exploring the Origins of Youth Media Production." Journal of Media Lite Education $6 \quad$ (2): 23-34. https://files.eric.ed.gov/fulltext/EJ1046508.pdf.

Hongisto, Salla. 2015. "Osallistava valokuvaus nuorten yhteiskunnallisen vaikuttamisen edistäjänä." [Participatory Photography in the Promotion of Societal Influencing of Youth]. Master's thesis, University of Tampere. http://urn.fi/URN:NBN:fi:uta201508182226.

Hopkins, Liza. 2010. "YouthWorx: Increasing Youth Participation through Media Production." Sociology 47 (2): 181-97. http://doi.org/10.1177/1440783310386827.

Jenkins, Henry, Ravi Purushotma, Margaret Weigel, Katie Clinton, and Alice J. Robison. 2009. Confronting the Challenges of Participatory Culture. Media Education for the $21^{\text {st }}$ Century. Cambridge: MacArthur Foundation. https://www.macfound.org/media/ article_pdfs/JENKINS_WHITE_PAPER.PDF

Keskitalo, Anne. 2006. Tien päällä ja leirissä: matkanteon kokemuksesta taideteokseksi [On the Road and in Camp: From the Experience of Travelling to a Work of Art]. Rovaniemi, Finalnd: Lappland University Press.

Kiuru, Inka. 2016. "Hyvin otettu kuva voi kertoa tarinan". Osallistava valokuvaus monikulttuurisessa nuorisotyössä ["Well Taken Photograph Can Tell a Story". Participatory Photography in Multicultural Youth Work]. Master's thesis, University of Tampere. http://urn.fi/URN:NBN:fi:uta-201608152167.

Kotilainen, Sirkku. 2009. "Suhteet mediaan—avainkokemuksia nykykulttuurissa." [Relations to Media-Key Experiences in Contemporary Culture] In Suhteissa mediaan [Relations to Media], edited by Sirkku Kotilainen, 7-18. Jyväskylä, Finland: University of Jyväskylä.

Liamputtong, Pranee. 2007. Researching the Vulnerable: A Guide to Sensitive Research Methods. London: SAGE.

Marsh, Kathryn. 2012. “The Beat Will Make You Be Courage: The Role of a Secondary School Music Program in Supporting Young Refugees and Newly Arrived Immigrants in Australia". Research Studies in Music Education 34 (2): 93-111. http://doi.org/10.1177/1321103X12466138. 
Myllynen, Milka. 2016. \#NUORETESTRADILLE \#KUULEKSMUA? Mediajulkisuus ja monikulttuurisen nuoren identiteetti [\#YoungPeopleintheLimelight \#Hearme? Media Publicity and the Identity of a Multicultural Young Person]. Master's thesis, University of Tampere. http://urn.fi/URN:NBN:fi:uta-201606232004.

Myrskylä, Pekka. 2012. Hukassa-Keitä ovat syrjäytyneet nuoret? [Lost-Who Are the Marginalised Young People?] Helsinki: EVA. http://www.eva.fi/wpcontent/uploads/2012/02/Syrjaytyminen.pdf.

Pariser, David, Juan C. Castro, and Martin Lalonde. 2016. "Mobilities, Aesthetics and Civic Engagement: Getting At-Risk Youth to Look at Their Communities." International Journal of Education through Art 12 (3): 211-25. http://doi.org/10.1386/eta.12.2.211_1.

Pienimäki, Mari and Sirkku Kotilainen. 2018. "Youth Participation in Research on Multiliteracies: Ethical Perspectives." Media Education Research 8 (1): 115-32. https://tampub.uta.fi/bitstream/handle/10024/103073/youth_participation_in_research_ on_multiliteracies_2018.pdf? sequence $=1 \&$ isAllowed $=$.

Podkalicka, Aneta, and Jonathan Staley. 2009. "YouthWorx Media: Creative Engagement for 'At Risk' Young People." 3CMedia: Journal of Community, Citizens and Third Sector Media and Communication 5 (October): 1-7. https://www.cbaa.org.au/article/youthworx-media-creative-media-engagement$\%$ E2\%80\%98-risk\%E2\%80\%99-young-people.

Puska, Maija. 2016. Luova kirjoittaminen ja mediakasvatus. Tarkastelussa työttömien nuorten mediasuhteet ja kirjoittaminen [Creative Writing and Media Education: Young People's Media Uses and Writing in Focus]. Master's thesis, University of Tampere. http://urn.fi/URN:NBN:fi:uta-201611072528.

Reason, Peter, and Hilary Bradbury. 2006. "Inquiry and Participation in Search of a World Worthy of Human Aspiration." In A Handbook of Action Research, The Concise Paperback Edition, edited by Peter Reason and Hilary Bradbury, 1-14. London: SAGE.

Rodríguez-Jiménez, Anthony, and Sandra M. Gifford. 2010. "Finding Voice: Learnings and Insights from a Participatory Project with Recently Arrived Afghan Young Men with Refugee Backgrounds.” Youth Studies Australia 29 (2): 33-41.

Ryan, Richard M., Veronika Huta, and Edward L. Deci. 2008. "Living Well: a SelfDetermination Theory Perspective on Eudaimonia." Journal of Happiness Studies 9 (1): 139-70. http://doi.org/10.1007/s10902-006-9023-4.

Salvio, Paula M. 2013. "Exercising 'The Right to Research': Youth-Based Community Media Production as Transformative Action." English in Education 47 (2): 163-80. http://doi.org/10.1111/eie.12019.

Sefton-Green, Julian. 2000. "Introduction: Evaluating Creativity." In Evaluating Creativity: Making and Learning by Young People, edited by Julian Sefton-Green and Rebecca Sinker, 1-16. New York: Routledge.

Silbereisen, Rainer K., and Richard M. Lerner 2007. "Approaches to Positive Youth Development: A View of the Issues." In Approaches to Positive Youth Development, edited by Rainer Silbereisen and Richard M. Lerner, 4-30. London: SAGE.

Vickery, Jacqueline R. 2014. "The Role of After-School Digital Media Clubs in Closing Participation Gaps and Expanding Social Networks." Equity \& Excellence in Education 47 (1): 78-95. http://doi.org/10.1080/10665684.2013.866870.

\section{ABOUT THE AUTHOR}

Mari Pienimäki: Postdoctoral Researcher, Faculty of Management, University of Tampere, Tampere, Pirkanmaa, Finland 
The International Journal of New Media, Technology, and the Arts is one of four thematically focused journals in the family of journals that support the Arts and Society Research Network -its journals, book imprint, conference, and online community. It is a section of The International Journal of the Arts in Society.

The International Journal of New Media, Technology, and the Arts explores technologies of arts production and reproduction old and new, including photography, film, video, multimedia, and the internet. Its interests range from image making, to spatial-architectonic arts, design, and online cultures. It also explores the workings and potentials of the "creative industries" in the postindustrial or knowledge society.

As well as papers of a traditional scholarly type, this journal invites presentations of practice-including experimental forms of documentation and exegeses that can with equal validity be interrogated through a process of academic peer review. This, for instance, might take the form of a series of images representing artistic practice, together with explanatory notes that articulate this practice with other, significantly similar or different and explicitly referenced practices.

The International Journal of New Media, Technology and the Arts is a peer-reviewed scholarly journal. 